\title{
Association of a PIT1 gene polymorphism with growth hormone mRNA levels in pig pituitary glands
}

\author{
Maurício Machaim Franco ${ }^{1,2}$, Robson Carlos Antunes ${ }^{1}$, Katiana Mello de Oliveira ${ }^{1}$, Cícero Donizete \\ Pereira $^{1}$, Fernando Henrique Biase ${ }^{1}$, Francis de Morais Franco Nunes ${ }^{3}$ and Luiz Ricardo Goulart ${ }^{1}$ \\ ${ }^{1}$ Universidade Federal de Uberlândia, Instituto de Genética e Bioquímica, Laboratório \\ de Genética Molecular, Uberlândia, MG, Brazil. \\ ${ }^{2}$ Embrapa Recursos Genéticos e Biotecnologia, Laboratório de Genética Molecular Animal, \\ Brasília, DF, Brazil. \\ ${ }^{3}$ Universidade de São Paulo, Faculdade de Medicina de Ribeirão Preto, Departamento de Genética, \\ Ribeirão Preto, SP, Brazil.
}

\begin{abstract}
Fourty-six non-castrated, halothane-free, male Landrace pigs were genotyped by PCR-RFLP for the Rsa I polymorphism in the PIT1 gene and classified into AA and AB genotypes. Total RNA was extracted from the pituitaries and the relative quantities of growth hormone $(\mathrm{GH}) \mathrm{mRNA}$ were determined by semi-quantitative RT-PCR. Pigs with the AB genotype had higher levels of GH mRNA than those with the AA genotype $(p=0.034$; Kruskal-Wallis test). This result suggests that the Rsa I polymorphism may be involved in Pit-1 protein expression or function, which in turn may influence GH transcription and expression. Thus, the Rsa I PIT1 gene polymorphism in this pig line may be used as a molecular marker to identify higher GH expression and possibly select for carcass and performance traits affected by $\mathrm{GH}$.
\end{abstract}

Key words: PIT1 gene, growth hormone mRNA, semi-quantitative RT-PCR, pig.

Received: September 25, 2003; Accepted: August 20, 2004.

\section{Introduction}

Pit-1 is a pituitary transcription factor for $\mathrm{GH}$, prolactin and TSH $\beta$ genes (Yu et al., 1995; Cogan and Phillips, 1998). Yu et al. (1995) studied the association between PIT1 polymorphisms and carcass and performance traits in pigs and concluded that this gene may be a candidate for a quantitative trait locus (QTL) in these animals. Supporting evidence for this has been provided by this same group, who identified a chromosomal region close to PIT1 with evidence of QTL (Yu et al., 1999). Stancekova et al. (1999) and Brunsch et al. (2002) also studied associations of PIT1 polymorphisms with carcass and performance traits, and also suggested that PIT1 might be a candidate gene for a QTL in pigs.

According to Parks et al. (1993), the Pit-1 protein is located in somatotroph, lactotroph and tireotroph nuclei, and alterations in GH secretion in humans may be caused

Send correspondence to Maurício Machaim Franco. Embrapa Recursos Genéticos e Biotecnologia, Avenida W/5 Norte Final, Parque Estação Biológica, Prédio Biotecnologia, Sala 7, 70770-900 Brasília, DF, Brazil. E-mail: mfranco @ cenargen.embrapa.br. by PIT1 gene mutations. Farmer et al. (1993) reported that pituitary GH secretion undergoes dramatic changes with age. In agreement with this, GH mRNA levels decrease with age, and this may be associated with the onset of puberty (Te Pas et al., 2001).

Matteri and Carroll (1997) studied male piglets (1, 7, $14,21,28,35$ and 42 days old) and found that the levels of PIT1 and GH mRNAs were significantly correlated, and that the quantity of GHRH receptor mRNA correlated with GH mRNA levels. Sun et al. (2002) obtained similar results for the age-dependent expression of PIT1. However, the polymorphisms detected in the PIT1 gene have not yet been shown to affect Pit-1 function or activity in pigs (Tuggle and Trenkle, 1996).

Several techniques for quantifying gene expression have been used, particularly dot blot and northern blot analyses (Taniyama et al., 1999), and semi-quantitative RTPCR (Uchide et al., 1999).

The purpose of this study was to investigate the association between the Rsa I polymorphism of the PIT1 gene and the relative levels of GH mRNA in pig pituitaries. 


\section{Material and Methods}

\section{Biological material}

To determine the levels of GH gene expression, 46 pituitaries were collected from Landrace pigs at Granja Rezende $\mathrm{S} / \mathrm{A}, \mathrm{Brazil}$. The pigs were classified into $\mathrm{AA}$ and $\mathrm{AB}$ genotypes ( $n=23$ each), based on the Rsa I polymorphism of the PIT1 gene. The frequency of the BB genotype in this population was $<1 \%$, so this genotype was not included in the study on GH gene expression.

All of the pigs were non-castrated males and were halothane-free, as confirmed by PCR-RFLP of the HAL gene (data not shown).

The animals were slaughtered during the months of May through July in accordance with Brazilian legislation, during which time the seasonal temperature was relatively constant (average of $22{ }^{\circ} \mathrm{C}$ ). The pigs were fasted for $24 \mathrm{~h}$ before slaughtering. One hour after slaughtering, the pituitaries were removed and immediately frozen in liquid nitrogen for transportation to the Molecular Genetics Laboratory of the Universidade Federal de Uberlândia (UFU), where they were stored at $-80^{\circ} \mathrm{C}$ until RNA extraction.

To search for an alternative splicing site, pituitaries of each of the three genotypes were used $(n=2$ each).

\section{DNA extraction}

For Rsa I polymorphism genotyping by PCR-RFLP, genomic DNA was obtained from blood samples by adding $1 \mathrm{~mL}$ of lysis buffer $20 \mathrm{mM}$ Tris- $\mathrm{HCl}, \mathrm{pH} 7.5,5 \mathrm{mM}$ ethylenediaminetetracetic acid (EDTA), $640 \mathrm{mM}$ sucrose, $10 \mathrm{mM} \mathrm{MgCl}_{2}, 4 \%$ Triton X-100 to $500 \mu \mathrm{L}$ of white blood cells kept on ice for $10 \mathrm{~min}$. The lysed cells were precipitated (white pellet) by centrifugation for $1 \mathrm{~min}$ at $7200 \mathrm{~g}$ and $4{ }^{\circ} \mathrm{C}$, followed by two or more washes with lysis buffer diluted 1:1 in water. The resulting pellet was digested with $10 \mu \mathrm{L}$ of proteinase $\mathrm{K}(10 \mathrm{mg} / \mathrm{mL})$ and $200 \mu \mathrm{L}$ of proteinase $\mathrm{K}$ buffer $(10 \mathrm{mM}$ Tris- $\mathrm{HCl}, \mathrm{pH} 7.5,1 \mathrm{mM}$ EDTA and $1 \%$ sarkosyl) by incubation overnight at $50^{\circ} \mathrm{C}$. After this, $500 \mu \mathrm{L}$ of $8 \mathrm{M}$ guanidine isothiocyanate $/ 0.49 \mathrm{M}$ ammonium acetate was added to the digested material, followed by shaking for $1 \mathrm{~h}$ at room temperature to dissolve the pellet. DNA was precipitated with $800 \mu \mathrm{L}$ of $100 \%$ isopropanol by centrifugation at $7200 \mathrm{~g}$ for $10 \mathrm{~min}$, and the supernatant was discarded. The pellet was washed once with $60 \%$ isopropanol and centrifuged at $7200 \mathrm{~g}$ for $2 \mathrm{~min}$. The DNA was dried and re-dissolved in $0.2 \mathrm{~mL}$ of TE (10 mM Tris-HCl, $\mathrm{pH} 7.5$, containing $1 \mathrm{mM}$ EDTA), followed by incubation at $65^{\circ} \mathrm{C}$ for $1 \mathrm{~h}$ to ensure complete suspension.

\section{Genotyping at the PIT1 locus}

Genotyping at the PIT1 gene was done using a pair of primers designed by Yu et al. (1994), with the following sequences: 5' AGTGTAGCCAGAGCATCT 3' (forward) and 5' ACCACATCTGCACACTCA 3' (reverse), which amplifies an amplicon of $1745 \mathrm{bp}$, corresponding to the region from intron 4 to the 3' untranslated region (3' UTR). The PCR reactions were carried out in a PTC-100 MJ Research thermocycler. After preheating at $95^{\circ} \mathrm{C}$ for $4 \mathrm{~min}$, amplification was done using 30 cycles at $95^{\circ} \mathrm{C}$ for $1 \mathrm{~min}$, $61{ }^{\circ} \mathrm{C}$ for $1 \mathrm{~min}$, and $72{ }^{\circ} \mathrm{C}$ for $3 \mathrm{~min}$. The final incubation was done at $72{ }^{\circ} \mathrm{C}$ for $5 \mathrm{~min}$. For the PCR assays, $2.5 \mathrm{U}$ of Taq DNA polymerase (Cenbiot Enzimas, Biotechnology Center - UFRGS, Porto Alegre, Brazil), 1X PCR buffer, $1.5 \mathrm{mM} \mathrm{MgCl}_{2}, 200 \mu \mathrm{M}$ of each dNTP, $0.4 \mu \mathrm{M}$ each of both primers, and $200 \mathrm{ng}$ of genomic DNA in a final volume of $25 \mu \mathrm{L}$ were used. After amplification, $15 \mu \mathrm{L}$ of the PCR amplicon were digested with $12 \mathrm{U}$ of Rsa I restriction enzyme for $8 \mathrm{~h}$ at $37^{\circ} \mathrm{C}$; genotyping was performed in $2 \%$ agarose gels stained with ethidium bromide $(10 \mathrm{mg} / \mathrm{mL})$, and photographed under UV illumination.

\section{RNA extraction}

Total RNA was extracted from pituitaries using Trizol reagent (Gibco BRL) according to the manufacturer's protocol, with a Trizol/sample weight ratio of $1.5 \mathrm{~mL}$ of Trizol per pituitary. All samples were quantified by spectrophotometry and diluted to $50 \mathrm{ng} / \mu \mathrm{L}$ in diethylpyrocarbonate (DEPC)-treated water.

\section{Semi-quantitative RT-PCR}

Total RNA from each pig was analyzed by semiquantitative RT-PCR, using Ready-To-Go ${ }^{\mathrm{TM}}$ RT-PCR beads (Amersham Biosciences) for the $\mathrm{GH}$ and $\beta$-actin genes. The GH gene primer pair was designed at the UFU Molecular Genetics Laboratory, using the Primer Designer program - version 2.0. The primers were based on the GH gene sequence (Vize and Wells, 1987). The $\beta$-actin gene primer pair was used to normalize the samples (Matteri and Caroll, 1997). The primers sequences were: GH - 5' CGATCGCAGAGGTACTCCATCCAGAA 3' (forward) and 5' CGATCGTATGTCTCAGCCTTGTGCAG 3' (reverse), which amplified a 418 bp product, and $\beta$-actin - 5' GCTGTATTCCCCTCCATCGT 3' (forward) and 5' ACGGTTGGCCTTAGGGTTCA 3' (reverse), which amplified a $264 \mathrm{bp}$ product.

Reverse transcription (RT) and PCR amplification reactions were subsequently performed, using the following conditions: $42^{\circ} \mathrm{C}$ for $30 \mathrm{~min}, 95^{\circ} \mathrm{C}$ for $5 \mathrm{~min}, 25$ cycles at $95^{\circ} \mathrm{C}$ for $30 \mathrm{~s}, 58^{\circ} \mathrm{C}$ for $40 \mathrm{~s}$, and $72^{\circ} \mathrm{C}$ for $1 \mathrm{~min}$. The final incubation was done at $72^{\circ} \mathrm{C}$ for $10 \mathrm{~min}$. Each RT-PCR mixture included $25 \mathrm{ng}$ of total RNA and $0.08 \mu \mathrm{M}$ of each primer in a final volume of $50 \mu \mathrm{L}$. Both genes were amplified simultaneously in the same tube.

The exponential phase of the RT-PCR was determined by using the same reaction conditions as described above for 20, 22, 25, 28, 30, and 35 cycles (data not shown). After amplification, $10 \mu \mathrm{L}$ of RT-PCR products were run in 
$2 \%$ agarose gels, stained with ethidium bromide $(10 \mathrm{mg} / \mathrm{mL})$, and photographed under UV illumination.

\section{Densitometric readings}

All samples were run in the same agarose gel, and the levels of expression were quantified by densitometry using ImageMaster $^{\mathrm{TM}}$ VDS Software version 2.0 (Amersham Biosciences). The relative quantities of GH mRNA were determined for each pig by the $\mathrm{IOD}_{\mathrm{GH}} / \mathrm{IOD}_{\beta}$-actin ratio, where IOD is the integrated optical density.

\section{Statistical analysis}

The differences in age and weight between AA and $\mathrm{AB}$ pigs was analyzed by using variance analyses, and the association between the PIT1 genotypes and the relative quantities of GH mRNA was analyzed by using the Kruskal-Wallis test, run in the Jandel SigmaStat program, version 2.0, 1995. The results are expressed as means \pm S.E.M. $\mathrm{p}$ values $<0.05$ indicated significance.

\section{Search for an alternative splicing site}

To search for an alternative splicing site within the region from exon 4 to 3' UTR of the PIT1 cDNA, RT-PCR was carried out with $200 \mathrm{ng}$ of total RNA from each of the three Rsa I PIT1 genotypes ( $\mathrm{n}=2$ each), using Readyto-Go ${ }^{\mathrm{TM}}$ RT-PCR beads (Amersham Biosciences).

The primers used were 5' ACCTACAGCTCAGC TTCA 3' (forward) and 5' ACCACATCTGCACACTCA 3 ' (reverse). The forward primer was designed at the UFU Molecular Genetics Laboratory. The reverse primer was described by Yu et al. (1994). A concentration of $0.2 \mu \mathrm{M}$ of each primer was used in a final volume of $50 \mu \mathrm{L}$. The RT and PCR amplification reactions were performed using the following conditions: $42{ }^{\circ} \mathrm{C}$ for $30 \mathrm{~min}, 95^{\circ} \mathrm{C}$ for $5 \mathrm{~min}$, 35 cycles at $95{ }^{\circ} \mathrm{C}$ for $30 \mathrm{~s}, 55^{\circ} \mathrm{C}$ for $40 \mathrm{~s}$, and $72{ }^{\circ} \mathrm{C}$ for $1 \mathrm{~min}$. The final incubation was done at $72^{\circ} \mathrm{C}$ for $10 \mathrm{~min}$.

After amplification, $15 \mu \mathrm{L}$ of the RT-PCR amplicons were run on $1.8 \%$ agarose gels, then stained with ethidium bromide $(10 \mathrm{mg} / \mathrm{mL})$, and photographed under UV illumination.

The smallest RT-PCR amplicon was cut from the agarose gel, macerated, filtered through a glass-wool plug by centrifugation at $6000 \mathrm{~g}$, and collected in a $1.5 \mathrm{~mL}$ microtube. Purification was done by adding $2 \mu \mathrm{L}$ of $7.5 \mathrm{M}$ ammonium acetate and $2 \mu \mathrm{L}$ of glycogen $(10 \mathrm{mg} / \mathrm{mL})$ to $8 \mu \mathrm{L}$ of filtered solution, which was mixed and incubated with an equal volume of $100 \%$ ethanol for $3 \mathrm{~h}$ at $-20^{\circ} \mathrm{C}$. The DNA solution was centrifuged at $19000 \mathrm{~g}$ for $5 \mathrm{~min}$, and the pellet was subsequently washed with $70 \%$ ethanol. The purified amplicon was cloned by using the TOPO TA cloning kit (Invitrogen Life Technologies), and the selected fragment was sequenced using a dideoxy fluorescence terminator system (ABI 377).

\section{Control reactions}

Negative controls for all semi-quantitative RT-PCR were obtained by using total RNA without reverse transcription, in order to check for DNA contamination. The total RNA from all samples used to search for an alternative splicing site was treated with RNase-free DNase I. Negative controls for all RT-PCR assays were run without DNA/RNA template.

\section{Results}

\section{Genotyping at the PIT1 locus}

The pigs were separated according to their PIT1 genotype, with an equal number $(n=23)$ per group. Figure 1 shows the genotype patterns. Allele A contained one $710 \mathrm{bp}$ fragment, whereas allele B had two fragments (388 and $322 \mathrm{bp}$ ). Monomorphic fragments of 774, 153 and $108 \mathrm{bp}$ were also present.

\section{RNA extraction, semi-quantitative RT-PCR and statistical analysis}

RNA extractions were of similar quality (Figure 2). Semi-quantitative RT-PCR produced a $418 \mathrm{bp}$ fragment for the $\mathrm{GH}$ and a $264 \mathrm{bp}$ fragment for the $\beta$-actin gene. The co-amplified amplicons are shown in Figure 3.

The statistical analysis showed no differences between $\mathrm{AA}$ and $\mathrm{AB}$ pigs regarding age and weight $(\mathrm{p}>0.05)$; the AA pigs were $141.56 \pm 1.01$ days old and weighed $92.60 \pm 1.36 \mathrm{~kg}$, while the $\mathrm{AB}$ pigs were

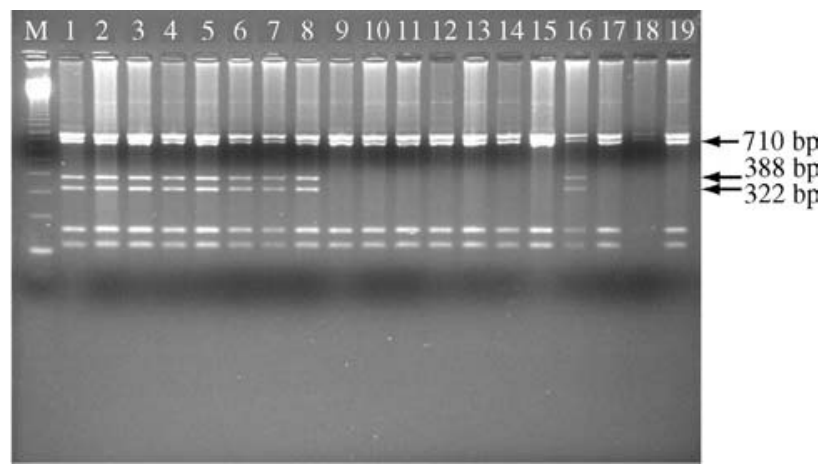

Figure 1 - Rsal polymorphisms in the PIT1 gene detected by PCR-RFLP. The PCR products were run on $2 \%$ agarose gels. M - 100 bp ladder of molecular weight markers (Gibco/BRL); lanes $1-8$ and 16 show the $\mathrm{AB}$ genotype; lanes 9 - 15 and 17 - 19 show the AA genotype. Allele A contained a $710 \mathrm{bp}$ fragment whereas allele B had two fragments, 388 and $322 \mathrm{bp}$, that are indicated by arrows. Monomorphic fragments of 774, 153 and 108 bp were also present.

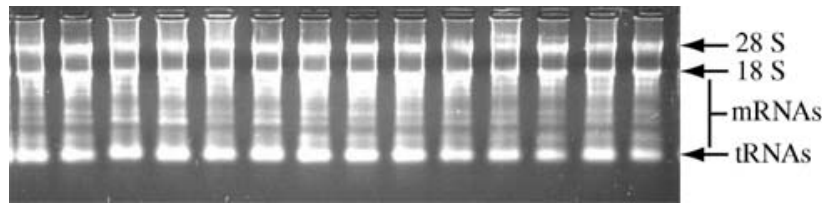

Figure 2 - The quality of the total RNA extracted from the pituitaries of 14 pigs. The samples were run on $1.2 \%$ agarose gels. 


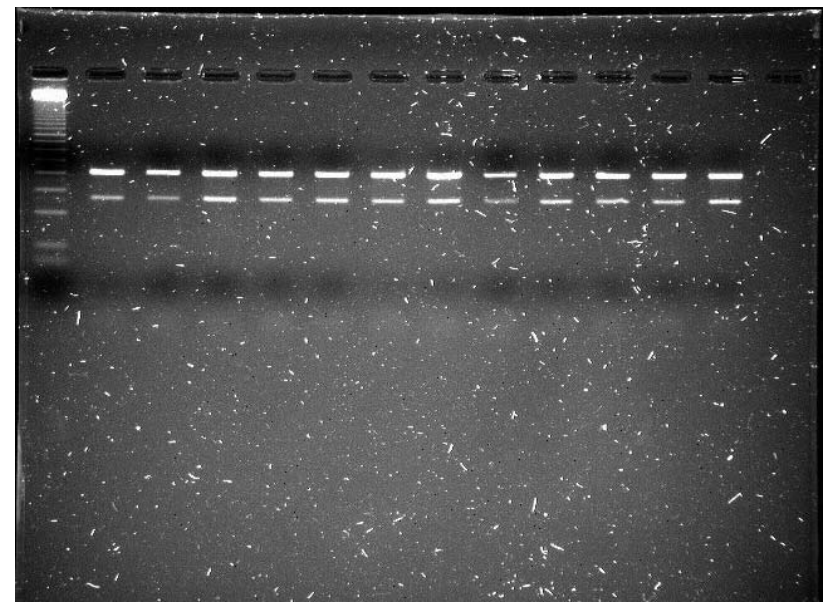

Figure 3 - Semi-quantitative RT-PCR for the GH gene. First lane - 100 bp ladder of molecular weight markers. The 12 lanes represent co-amplified samples of GH cDNA (418 bp) and the $\beta$-actin cDNA (264 bp). Lanes 1-6 show the AB genotype; lanes 7-12 show the AA genotype. The samples were run on $2 \%$ agarose gels.

$142.65 \pm 0.93$ days old and weighed $89.23 \pm 2.00 \mathrm{~kg}$. Besides that, the relative abundance of GH mRNA was higher in $\mathrm{AB}$ pigs than in $\mathrm{AA}$ pigs: $2.37 \pm 0.15$ in $\mathrm{AA}$ pigs, and $3.52 \pm 0.40$ in $A B$ pigs $(p=0.034)$.

\section{Alternative splicing site}

The RT-PCR amplifications from exon 4 to 3'-UTR of PIT1 cDNA generated two stronger bands, $650 \mathrm{bp}$ and $496 \mathrm{bp}$, including the primer sequences (Figure 4). The $650 \mathrm{bp}$ fragment had the expected size based on the PIT1 cDNA sequence, whereas the 496 bp fragment could be an alternative splicing fragment. After sequencing, the smallest fragment was deposited at GenBank (accession number AY309500) and used to search for homology in the GenBank database using BLAST software (www.ncbi. nlm.nih.gov/blast). No homology was found for the PIT1 gene as expected, but it showed high homology with Homo

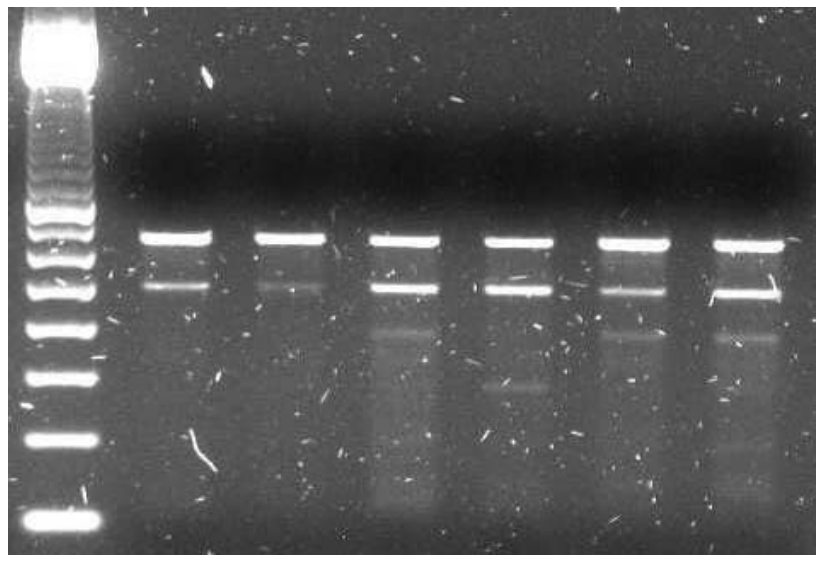

Figure 4 - PIT1 cDNA amplicons. First lane - 100 bp ladder of molecular weight markers. Lanes 1 and 2 - genotype $\mathrm{AB}$; lanes 3 and 4 - genotype $\mathrm{BB}$; lanes 5 and 6 - genotype AA. The samples were run on $2 \%$ agarose gels. sapiens and Mus musculus A kinase (PRKA) anchor protein 13 isoform genes. These primers are specific for the PIT 1 gene sequence of the pig, but they probably bound unspecifically and sufficiently to generate the smallest fragment.

\section{Control reactions}

Figure 5 shows the control reactions for DNA contamination in the total RNA samples.

\section{Discussion}

For semi-quantitative RT-PCR 25 cycles were used, since at this number the reaction was in its exponential phase, an important and necessary condition for the quantification of gene expression. The two primer pairs were co-amplified in the same reaction tube, thus avoiding different amplification conditions and reducing the possibility of mistakes. An internal control ( $\beta$-actin) was used to normalize the quality and quantity of the RNA samples, as discussed by Siebert and Larrick (1992). This method for quantifying gene expression is fast and efficient and is an important tool in gene expression studies.

Tatsumi and Amino (1999) showed that the Pit-1 protein was involved in modulating the expression of $\mathrm{GH}$, TSH, prolactin and PIT1 genes. Korytko et al. (1996) mentioned that little is known about GHRH receptor regulation, although Pit-1 may modulate its expression.

Te Pas et al. (2001) studied the growth rate and the reduction in back fat thickness in Large White pigs, as well as changes in the mRNA levels of GH and PIT1 genes, and concluded that for each generation of selection the GH and PIT1 mRNA levels increased by $50 \%$. Nevertheless, there was considerable variation in the mRNA levels of both genes among animals within each generation.

The availability of a DNA marker related to the variations in GH and PIT1 mRNA levels could be useful for identifying and selecting animals with favorable genotypes.

As shown here, Rsa I genotypes in the PIT1 gene presented an association with GH mRNA levels, suggesting

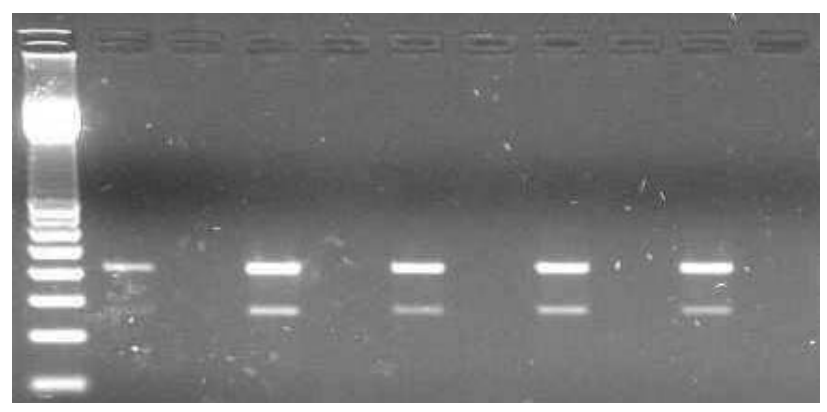

Figure 5 - The control of DNA contamination using total RNA. First lane $100 \mathrm{bp}$ ladder of molecular weight markers. Lanes 1, 3, 5, 7, and 9 are amplicons of GH cDNA (418 bp) and the $\beta$-actin cDNA (264 bp) obtained using untreated total RNA with RNase-free DNase I as template. Lanes 2, $4,6,8$, and 10 are equal reactions with untreated total RNA without reverse transcription. The samples were run on $2 \%$ agarose gels. 
that this polymorphism may be a useful molecular marker for production traits that are controlled by $\mathrm{GH}$.

This conclusion is reinforced by the findings of Sun et al. (2002), who observed an important association of an Msp I PIT1 polymorphism with the plasma levels of GH and PRL, which suggested an association between this genotype and gene expression in the pituitary. Together, these results show the important physiological effect of the PIT1 gene on other genes in this gland.

Yu et al. (1999) detected a strong association between PIT1 polymorphism and microsatellites that flank this gene and the phenotypic traits of young animals. The expression of PIT1 is age-dependent, with higher expression in young animals. Matteri and Carroll (1997) also observed agedependent changes in the expression of various other genes.

As shown here, an association between PIT1 gene polymorphism and GH mRNA expression was detected close to puberty. Although the importance of PIT1 in early life has been shown previously, we also found an association between this gene polymorphism and the level of GH gene expression in adult animals.

The genes involved in the pathway of GH action have great potential as molecular markers, with a direct application for animal production, because of their physiological effects on bone and muscle growth, fat metabolism and other important effects on animal development. Most of the studies in this area have used humans, mice and rats as models, with few studies of economically important animals. Studies of candidate genes based on direct physiological effects are simple and straightforward, as compared to the use of anonymous DNA markers, which requires long, labor-intensive protocols.

The results shown here suggest that the Rsa I polymorphism could be related with levels of PIT1 gene expression. This polymorphism could be involved in the production of alternative transcripts, thereby altering the protein and its function. Since the Pit-1 protein is involved in GH expression, a difference in GH mRNA levels would be expected with different PIT1 genotypes.

The presence of two amplicons in the RT-PCR amplification of the PIT1 region from exon 4 to the end of the cDNA, containing the Rsa I mutation in intron 5, raised the possibility of alternative gene splicing. The $650 \mathrm{bp}$ fragment (Figure 4) had the expected size based on the known gene sequence, whereas sequencing of the smallest $496 \mathrm{bp}$ fragment (accession number AY309500) showed that it was not an alternative transcript, since BLAST analysis indicated high homology with Homo sapiens and Mus musculus A kinase (PRKA) anchor protein 13 isoform genes. It is the first time that this sequence is described in pigs.

The possible interference of this mutation with other alternative splicings, already described (Tuggle and Trenkle, 1996), remains to be determined. Furthermore, the quantification of PIT1 mRNA may also associate this mutation with PIT1 self-expression.

The Rsa I PIT1 polymorphism may be related to GH mRNA levels through self-regulation of the PIT1 gene and/or interference with the production of alternative gene transcripts. Either of these possibilities would result in altered PIT1 gene expression and consequently in GH gene expression. Additional studies to analyze the PIT1 gene expression will be important for a better understanding.

We can conclude that this PIT1 polymorphism may be a useful molecular marker for selecting higher $\mathrm{GH}$ mRNA levels as well as phenotypic traits related to $\mathrm{GH}$ action in this population.

\section{Acknowledgements}

The authors thank Rezende Alimentos S/A for providing the biological material.

\section{References}

Brunsch C, Sternstein I, Reinecke P and Bieniek J (2002) Analysis of associations of PIT1 genotypes with growth, meat quality and carcass composition traits in pigs. J Appl Genet 43:8591.

Cogan JD and Phillips III JA (1998) Growth disorders caused by genetic defects in the growth hormone pathway. Adv Pediatr 45:337-361.

Delhase M, Vila V, Hooghe-Peters EL and Castrillo JL (1995) A novel pituitary transcription factor is produced by alternative splicing of the human GHF-1/PIT1 gene. Gene 155:273-275.

Farmer C, Pommier SA and Brazeau P (1993) Validation of a culture system for porcine pituitary cells: Effects of growth hormone-releasing factor and(or) somatostatin on growth hormone secretion. J Anim Sci 71:923-929.

Korytko AI, Zeitler P and Cuttler L (1996) Developmental regulation of pituitary growth hormone-releasing hormone receptor gene expression in the rat. Endocrinology 137:13261331.

Matteri RL and Carroll JA (1997) Somatotroph function in the neonatal pig. Domest Anim Endocrinol 14:241-249.

Parks JS, Abdul-Latif H, Kinoshita E, Meacham LR, Pfaffle RW and Brown MR (1993) Genetics of growth hormone gene expression. Horm Res 40:54-61.

Pfaffle RW, Kim C, Blankenstein O and Kentrup H (1999) GH transcription factors. J Pediatr Endocrinol Metab 12:311317.

Siebert PD and Larrick JW (1992) Competitive PCR. Nature 359:557-558.

Stancekova K, Vasicek D, Peskovicova D, Bulla J and Kubek A (1999) Effect of genetic variability of the porcine pituitary-specific transcription factor (PIT1) on carcass traits in pigs. Animal Genetics 30:313-315.

Sun HS, Anderson LL, Yu T-P, Kim K-S, Klindt J and Tuggle CK (2002) Neonatal Meishan pigs show POU1F1 genotype effects on plasma GH and PRL concentration. Anim Reprod Sci 69:223-237.

Taniyama S, Kitahashi T, Ando H, Ban M, Ueda H and Urano A (1999) Changes in the levels of mRNAs for GH/prolactin/ 
somatolactin family and PIT1/GHF-1 in the pituitaries of pre-spawning chum salmon. J Mol Endocrinol 23:189-198.

Tatsumi K and Amino N (1999) PIT 1 abnormality. Growth Horm IGF Res Suppl B 18-22.

Te Pas MFW, Freriksen JWM, Van Bijnen AJHM, Gerritsen CLM, Van Den Bosch TJ, Harders FH, Verburg FJ, Visscher AH and De Greef KH (2001) Selection for growth rate or against back fat thickness in pigs is associated with changes in growth hormone axis plasma protein concentration and mRNA level. Domest Anim Endocrinol 20:165184.

Tuggle CK and Trenkle A (1996) Control of growth hormone synthesis. Domest Anim Endocrinol 13:1-33.

Uchide T, Masuda H, Mitsui Y and Saida K (1999) Gene expression of vasoactive intestinal contractor/endothelin-2 in ovary, uterus and embryo: Comprehensive gene expression profiles of the endothelin ligand-receptor system revealed by semi-quantitative reverse transcription-polymerase chain reaction analysis in adult mouse tissues and during late embryonic development. J Mol Endocrinol 22:161-171.

Vize PD and Wells JRE (1987) Isolation and characterization of the porcine growth hormone gene. Gene 55:339-344.

Yu TP, Schmitz CB, Rothschild MF and Tuggle CK (1994) Expression pattern, genomic cloning and RFLP analyses of the swine PIT1 gene. Anim Genet 25:229-233.

Yu TP, Tuggle CK, Schmitz CB and Rothschild MF (1995) Association of PIT 1 polymorphisms with growth and carcass traits in pigs. J Anim Sci 73:1282-1288.

Yu TP, Wang L, Tuggle CK and Rothschild MF (1999) Mapping genes for fatness and growth on pig chromosome 13: A search in the region close to the pig PIT1 gene. J Anim Breed Genet 116:269-280.

Associate Editor: Mayana Zatz 